\title{
Moments of possibility in politics, policy and practice in New Zealand citizenship education
}

\author{
Milligan, A., Mutch, C., \& Wood, B. E. (2020). Moments of Possibility in Politics, Policy, and
} Practice in New Zealand Citizenship Education. In A. Peterson, G. Stahl, \& H. Soong (Eds.), The Palgrave Handbook of Citizenship and Education (pp. 329-342). Cham: Springer International Publishing.

\author{
Andrea Milligan ${ }^{a}$, Carol Mutch ${ }^{b}$ and Bronwyn Wood $^{a}$ \\ a. Victoria University of Wellington \\ b. The University of Auckland
}

\begin{abstract}
The history of citizenship education in New Zealand has entailed several key moments that have been subject to contested historical, social, political and economic forces. While there has never been a stand-alone citizenship education curriculum in New Zealand, the social studies curricula remain the primary vehicle for citizenship education delivery since its origins in 1944. This chapter examines the development of citizenship education, through New Zealand's social studies curricula, as an 'education ensemble' in which five historical moments of "politics, policy and practice" (Dale, 2017) emerged. Examining these moments against a critical theoretical lens, this chapter considers the possibility such moments held for the development of more critical and active citizens. The authors analyse the more recent emphasis on social inquiry and social action as two further moments of possibility for enhancing critical and active citizenship. This analysis attests to the potential for critical change through curriculum reform, but also, in contrast, the potential for an enduring minimal, content-heavy, and neoliberal approach to learning citizenship in the absence of seizing a curriculum moment. In doing so, the chapter contributes to wider debates about how citizenship curricula is positioned within an ensemble of competing political agendas, practitioner influences, and policy frameworks.
\end{abstract}

Keywords: citizenship education, politics, policy, practice, ensemble, New Zealand 


\section{Citizenship education as an education ensemble}

The concept of an educational ensemble (Robertson \& Dale, 2015) challenges the idea that singular, immutable structures or powerful discourses are necessarily the best explanations for the way in which education is shaped in any given context. Instead, the idea of an ensemble highlights the fluid and dynamic impact of multiple and contesting forces, both visible and invisible, that coalesce to create the current situation and, in turn, influence future directions. To investigate the past, present and future of citizenship education, we draw on Robertson and Dale (2015) and Dale (2017), especially where Dale (2017) highlights the interrelatedness of moments of politics, policy and practice in influencing educational outcomes. In this chapter, this is applied to debates about the best way to prepare children and young people through citizenship education for their future as citizens of this country (Figure 1).

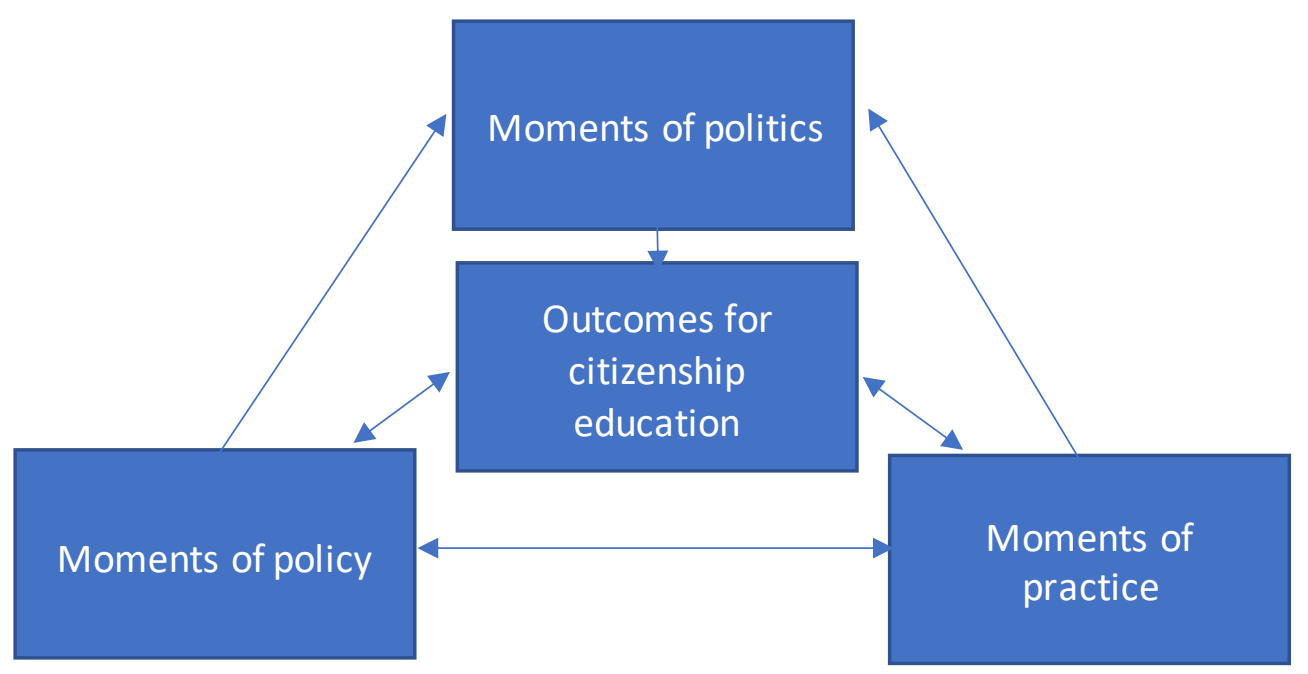

Figure 1: Moments of possibility in politics, policy and practice in citizenship education in New Zealand (Adapted from Dale, 2017)

Moments of possibility can be bifurcations, that is, forks in the road where particular notions of the ideal citizen are emphasised, marginalized, or not yet imagined. There is not the space here to analyse extensively gains and losses in the twists and turns in New Zealand's history of social studies and citizenship education. Instead, this chapter uses 'moments of possibility' to describe, with the benefit of hindsight and without suggesting a seamless narrative, the extent to which approaches to citizenship education in New Zealand could be considered 'critical' and 'active'. These terms loosely define a more 'maximal' approach to citizenship education, which McLaughlin (1992) described as promoting discussion, debate, active participation and critical thinking. In contrast, minimal approaches focus on learning about civics and citizenship but not engaging in it (McLaughlin, 1992). The authors suggest that a framework for 'critical' and 'active' citizenship education includes the following dimensions:

1. flexible, open and inclusive understandings of how citizenship is constituted; 
2. considerable knowledge of the complexity of society and the contested nature of social issues;

3. critical links to real world social issues;

4. support for active responses (Wood \& Milligan, 2016. p. 69-70).

These components are founded broadly upon critical theory. This holds as its goals a commitment to expose how power relations and inequality are manifest within cultural, political and social institutions, reveal the practices that serve to create inequalities and injustices in society, and social transformation, especially for those who hold the least power (Apple, Au, \& Gandin, 2009). When applied to citizenship education, this approach evokes goals of critical societal understandings, in which young people learn to critique social issues and systemic historic and contemporary injustices, and also develop the skills and ability to participate with active responses.

The following section presents a critique of five 'moments' in the historical development of citizenship education, culminating in The New Zealand Curriculum (Ministry of Education, 2007). The section focuses on social studies - as the primary vehicle of citizenship education in New Zealand (Archer \& Openshaw, 1992) - and how a competing ensemble of political agendas, policy debates, and practical realities led to different outcomes that, to a greater or lesser degree, enabled the emergence of a critical and active citizen.

\section{Moments of possibility in the history of citizenship education in New Zealand}

The first moment of possibility to provide children and young people with preparation for citizenship came with the Education Act of 1877. Politically, it was in response to the need to keep children and young people usefully occupied in the newly established British colony. Policy-wise, the Act was forward-looking, establishing a schooling system that was free, compulsory, and secular. New Zealand's first formal curriculum for primary-aged children provided a wide-ranging liberal education, including geography, nature study, music and drawing (Bailey, 1977). The practice, however, did not live up to the promise. While the curriculum was described as, "more ambitious in aim than any in the British Empire" (McLaren, 1980, p. 22), there were few teachers available to teach the curriculum in the manner in which it was intended, large class sizes, and inappropriate buildings (May, 2011). Māori were excluded from this curriculum and instead educated under the 1967 Native Schools Act, which "aimed to bring an uninitiated but intelligent and high spirited people into line with our civilisation" (Bailey, 1977, p. 5) and to prepare them for roles in labouring or domestic service (Simon, 1994). The arrival of the First World War further amplified these ideas. The curriculum became harnessed to the war effort, constantly reminding children of their duty to the Empire and promoting the values of heroism and self-sacrifice (Perreau \& Kingsbury, 2017). However, in curriculum policy, the desire for greater national loyalty and strong character was maintained in a 1928 school curriculum. This was a missed opportunity to forge an education system 
that prepared children and young people as citizens for the more egalitarian society that was forming in New Zealand, without the yoke of a rigid class system (Simon, 1994).

In the 1930s, a second moment of possibility presented itself. Ideas from the New Education Fellowship, a progressive education movement with its genesis in Europe, became noticed in New Zealand (Abbiss, 1998). This coincided with the election of the first Labour government, with its promise of a fairer society following the hardship of the Great Depression (Alcorn, 1999). Education was to be the vehicle to achieve this aim. By 1944, the influential Thomas Report (Department of Education, 1944) set the scene for the establishment of social studies as "an integrated course of history and civics, geography and some descriptive economics"(Shuker, 1992, p. 36) and part of a core curriculum for the first two years of secondary schooling. The curriculum was to prepare young people to value democracy and to take an "active place in New Zealand as a worker, neighbour, homemaker and citizen" (Department of Education, 1944, p. 5). The expectation that young people would begin to identify and solve social problems, that is, exercise judgement, is somewhat distinguishable from the civics focus in the former 1877 and 1928 syllabi. This showed a small nod towards critical and active citizenship, but not a significant one.

Throughout the 1960s and 70s, a third moment of possibility occurred. Politically, in New Zealand, the period of social and economic stability of the 1960s, was about to be challenged by economic downturn and social change movements, such as feminism, anti-war protests and minority rights (Dunstall, 1981). Responses to a changing society were echoed in policy. Social studies became aligned with a more responsive and active citizenship approach. The 1961 curriculum and a subsequent series of handbooks stated that social studies aimed to get students, "to think clearly about social problems, act responsibly and intelligently to social situations..." (Department of Education, 1961, p. 1). Looking back, it is also notable that little was said about how students were to address social problems other than the expectation that students would act intelligently and responsibly.

In the 1970s, in line with the "new social studies" movement, social studies in New Zealand became more multi-disciplinary, including, for example, teaching sociological and anthropological concepts alongside those from history, geography and economics. Social studies aimed to get students to "respect human dignity, to show concern for others, to respect and accept the idea of difference and to uphold social justice" (Department of Education, 1977,p. 4). A new Forms 1-4 (middle) school curriculum was approached via four themes: cultural difference, interaction, social control and social change. An important development over this time was the notion that it was not enough to be taught social knowledge and abilities, but that values awareness and analysis, together with taking social action to address injustices were important. These two curricula paved the way for ideas-led (as opposed to facts-driven) learning through processes of self-critical, reflective inquiry and the importance of developing active citizen responses to social issues which continue underpin the structure of the social studies curriculum today. 
With social studies now entrenched as the vehicle for citizenship education, its fortunes became entwined in a highly contested fourth moment of possibility in the 1980s and 90s. At this time, the politics that underpin the competing discourses surrounding the 'good citizen' (Archer \& Openshaw, 1992) emerged in a more blatant way the before. This political moment emerged against a backdrop of a worldwide economic downturn that was felt keenly in New Zealand. A new Labour Government, in 1984, inherited a funding shortfall from the previous government, and in line with the market-led neoliberal ideology of the time, set about radically restructuring health, education and social welfare to ensure the country remained financially viable and globally competitive. The social sciences (the umbrella term for social studies, history, economics, and geography) still had a place but their purpose was hotly contested (Mutch, 2008) as demonstrated by the 'curriculum wars' which ensued in the 1990s (Openshaw, 2000). The stand-alone social studies curriculum was re-written three times before it was finally mandated. The first version was not acceptable to conservative business interests or the Ministry of Education. Another writing team was formed. This second, more traditional, curriculum was not accepted by teachers. Finally, a compromise was reached (Mutch, 2004). In the third version, the subject's stated aims were to "enable students to participate in a changing society as informed, confident and responsible citizens" (Ministry of Education, 1997, p. 8).

Continuing social studies' focus on social problems, the 1997 document placed considerable emphasis on societal issues. In addition, it affirmed and considerably amplified the valuing, decisionmaking and social participation elements social studies. The separate social studies skills were crystalised as three inter-related processes - inquiry, values exploration, and social decision-makingthat were leading features of social studies curriculum design. A much stronger sense of criticality was also evident throughout the curriculum, within the social studies processes, and through the expectation that students would explore different worldviews (perspectives). For example, students were now to be "challenged to think about the nature of social justice" (Ministry of Education, 1997, p. 17), rather than accept concern for social justice as a commonly held value. Nevertheless, in order to reach a compromise between politics, policy and practice, a stronger civics thread appeared in the social organisation content strand. Social action, however, was watered down to a less controversial "social decision making" process strand. Further, as has always been the case, opportunities for critical reflection were tempered by encouraging particular commitments, most notably expressed in the Attitudes and Values section of 1997 document.

The final moment of possibility in this historical overview leads us through to the 2000s. In 2003, social studies became an examinable subject in the National Certificate of Educational Achievement [NCEA]. Prior to that, students had to select a senior social science subject such as history or geography. This change provided greater status for social studies in the senior years, and offered a qualifications pathway for students with an interest in the critical and active dimensions of citizenship. In addition, a curriculum review (Ministry of Education, 2002) led to previously separate learning area statements becoming two national curricula: The New Zealand Curriculum (Ministry of 
Education, 2007) and a version in te reo Māori. Rather a direct translation, this version, $T e$ Marautanga o Aotearoa (Ministry of Education, 2008a) draws on a Māori worldview to frame the content, understandings and approaches for teaching the curriculum in Kura Kaupapa Māori (Māori immersion schools) or schools with bi-lingual classes. However, despite the curriculum review also recommending a stronger focus on citizenship education as a cross-curricular theme (along with social cohesion and education for a sustainable future), no specific citizenship education statement exists within New Zealand's English-medium curriculum. Citizenship education instead appears in an aspirational manner within the curriculum's vision, values, and principles, and in a practical manner through the key competencies and recommended pedagogical approaches such as future-focussed themes (Mutch, 2010). The main vehicle for citizenship education remains the social sciences, specifically social studies. However, the goals of citizenship education are characterised by a pastiche of competing claims (Kliebard, 1986), including the idea of the twenty-first century learner which is positioned as a more 'active' type of learner to meet the needs of a rapidly changing global marketplace. Notably, the Māori-medium version of the social studies curriculum adopts a more critical theoretical position that aims to address historical injustice more openly than the Englishmedium version (H. Dale, 2016).

\section{Moments of possibility in present debates around citizenship education}

The historical summary of key moments of possibility in politics, policy and practice in citizenship education highlights the politically contested and socially constructed (Cornbleth, 1990) nature of the curriculum in New Zealand. This section discusses dilemmas and possibilities that have arisen since the 2007 curriculum.

Like many other nations, the challenges of equity and meeting the demands of a complex, changing society are significant policy concerns. In 2009, New Zealand participated in the International Civics and Citizenship Education Study [ICCS], (Schulz, Ainley, Fraillon, Kerr, , \& Losito, 2010). The ICCS highlighted both strengths and weaknesses in the New Zealand approach to citizenship education. New Zealand students performed well above the international average (517 points compared to 500) with $35 \%$ achieving scores at the highest proficiency level (Level 3). The ICCS assessment, however, confirmed the ethnic disparity in achievement that was apparent in other national and international assessments, that is, that students identifying with Pākehā or Asian ethnic groups did better than Māori or Pasifika students (Bolstad, 2012). The policy response to challenges such as these has largely occurred through system-wide and pedagogical levers, and has not involved curriculum review. However, in the decade since the publication of The New Zealand Curriculum (Ministry of Education, 2007), a range of subtle mechanisms have elaborated and re-worked the curriculum's rather concisely drawn expectations. For example, within a series of 'curriculum updates', a 2011 statement re-emphasised the need for citizenship education as a key cross-curricular and future-focused theme along with sustainability, enterprise and globalisation (Ministry of 
Education, 2011). Two further mechanisms are particularly notable because they specifically signal a shift in practice and offer the possibility for more critical and active approaches to citizenship education for the future: namely, the elaboration of social inquiry within curriculum support documents and an increasing focus social action within the context of NCEA assessment. These are discussed in turn.

\section{Social inquiry}

Using a social inquiry approach, the 2007 social studies curriculum strongly recommended that students:

- ask questions, gather information and background ideas, and examine relevant current issues

- explore and analyse people's values and perspectives

- consider the ways in which people make decisions and participate in social action

- reflect on and evaluate the understandings they have developed and the responses that may be required (p.30).

At the time of publication, this methodology was likely familiar to many New Zealand social studies educators, particularly given a persistent focus on inquiry operations since the 1970s and the tradition of reflective inquiry that has informed social studies, social sciences, and citizenship curricula internationally. However, while the processes of inquiry, values exploration, and social decisionmaking within this methodology were clearly identifiable in the 1997 statement and in a series of exemplars that demonstrated how the processes enhance learning in relation to social studies achievement objectives (Ministry of Education, 2004), the term 'social inquiry' was still new in the 2007 curriculum and established 'an appropriate and distinctive approach for studying human society' (Ministry of Education, 2008b, p. 4).,

The 2007 curriculum statement sketched the details of social inquiry rather lightly; a small section within a one-page description of the social sciences learning area as compared to greater detail and achievement indicators provided in the 1997 document. One of the immediate effects of this was a widespread confusion between social inquiry and 'teaching as inquiry', a model of reflective professional practice that was also included in the curriculum. However, a key opportunity to elaborate social inquiry, now the name given to the overarching methodology, rather than an aspect of it, came through the Building conceptual understandings in the social sciences [BCUSS] (Ministry of Education, 2008b, 2008c, 2009, 2012). This series of booklets provided second-tier support material for the implementation of the 2007 curriculum, one of which specifically focussed on approaches to social inquiry (Ministry of Education, 2008b). While the 1997 document envisaged the social studies processes as inter-related, these booklets did much to emphasise, through text and imagery, the reiterative nature of seven interconnected aspects: framing a conceptual focus for learning, finding out information, exploring values and perspectives, considering decisions and responses, so what, now what, and reflection and evaluation. In many ways this catch-all social inquiry approach attempted to 
outline an approach that held the possibility of meeting the citizenship aims of more informed, reflective, active and critical citizens through the study of society.

The explanation of social inquiry in the BCUSS documents preserved a procedural orientation to inquiry that was evident in previous curricular iterations and, at the same time, sustained the critical and active dimensions. Students were, for example, now encouraged to explore the contested nature of concepts, missing perspectives, and to consider the decisions or actions that they might make/take in relation to their social inquiry (Ministry of Education 2008c). This encouragement notwithstanding, the critical and active dimensions of citizenship were somewhat underdrawn in the BCUSS series. Social action is, for example, a suggestive aspect of social inquiry and largely positioned as an outcome rather than a site of critical reflection. As a result, the extent to which social studies teachers read citizenship outcomes as involving the critique of social issues and injustices, and the skills and ability to take active responses, is an open question. This 'moment lost' has not been helped by a tendency - at least in the authors' experience - for social inquiry to be collapsed into more generic models in primary school settings and for the 'hard bits' (Keown, 1998) such as the contested nature of knowledge and values to be dropped out. Furthermore, few other citizenship education resources produced by government, non-governmental organizations, or commercial publishers have deeply engaged with the opportunities for a critical and active approach to citizenship education (Tallon \& Milligan, 2018).

In the absence of strong curricular direction, there appears a vital need for encouraging more 'maximal' readings of social inquiry. A step towards this lies in a more recent elaboration of this model, 'social inquiry for social action' (Mutch et. al., 2016). This is perhaps the most explicit expression of the transformation potential for social inquiry published to date. The authors demonstrate how social inquiry can be read in a more critical light, with social justice as a visible aim of both inquiry and action. They propose, for example, a series of 'acceptability criteria' for selecting social inquiry resources based on their social justice content, such as the visibility of social justice movements and an acknowledgement of the central importance of social action within democracy . Arguably, similar criteria could be extended to the entirety of the social justice model. Indeed, what appear lacking in this current moment in time is shared, national agreement about what constitutes robust social inquiry and/or tools that enable teachers to evaluate the strength of their approach. In the absence of this, it is quite possible for educators and policy makers to social inquiry as containing a less ambitious intent.

\section{Social action:}

Notions of more 'active' citizens were prevalent across the 2007 New Zealand Curriculum and, as discussed above, prominent in social studies. This heightened focus on social action the New Zealand social studies curriculum mirrors trends in many citizenship education curricula seen elsewhere (Davies, Evans, \& Peterson, 2014; Ross, 2008). The impetus for a more active curriculum is difficult 
to pin down to one or two single factors, and instead is more likely to have emerged from an ensemble of multiple and complex relationships (Robertson \& Dale, 2015). In keeping with the timing of the launch of the 2007 New Zealand Curriculum, Nelson and Kerr's (2006) analysis of active citizenship across 14 countries found that changing societal patterns and challenges - such as migration, economic flows, globalisation, and environmental issues - and the need for an active citizenry to address such concerns were key to the growth of more active approaches. Further, the global promotion of themes associated with the 'knowledge age' (OECD, 1996) and key competencies (OECD, 2005) required a greater commitment to creativity, innovation, and problem-solving in order to keep up with the skills required for the $21^{\text {st }}$ century and the demands of a global educational marketplace, which in turn encouraged more 'active' ideas about learning (Gilbert, 2005; Nelson \& Kerr, 2006; Wood \& Sheehan, 2012). A final, less well-known impetus was from social studies teachers involved in curriculum and NCEA assessment development who, in the words of one curriculum writer, decided that "we were sick of our students just studying about the social action of others and wanted to have a chance for them to take social action themselves on issues, so we just thought we'd give it a go and write social action into the curriculum" (pers. comm. Greenland, August 2017). This combination of critical, cultural, political and economic factors contributed to the structures and relations which underpinned the development of the 2007 NZC and the stated outcome of social studies, that students will "participate and take action as critical, informed, and responsible citizens (Ministry of Education, 2007 , p. 17). The curriculum created a moment of possibility, with arguably a more critical and active notions of social action (Abbiss, 2011; Wood et al., 2013).

Despite this curriculum endorsement, research about the application of social action in by New Zealand social studies teachers has shown that social action is viewed as one of the 'hard bits' of social studies (Keown, 1998). For example, Taylor's (2008) postal survey of 45 social studies teachers found that while a few embraced the active citizenship potential of the curriculum, many expressed caution, noting concerns about controversy in the social issues studied and fears of indoctrination. Similarly, Wood's study of four diverse social studies departments identified that teachers were anxious about the expectations that social action could place on students, as well as concerned about health and safety compliance and management when students engaged with the local community (see Wood et al., 2013, pp., for a fuller description of these two studies). A 2015 survey of 145 social studies teachers identified similar patterns (Wood, Taylor, Atkins, \& Johnston, 2017), with the lack of implementation of social action by some teachers attributed to the time-consuming nature of taking social action and the anxiety of the 'riskiness' of the standards. These studies confirm earlier research findings that show that social action still represents a challenging aspect of social studies teaching - even with a heightened support in both curriculum and assessment policies.

However, while there has not been a wholesale adoption of social action since the 2007 curriculum, there is evidence of an increasingly active response to social studies, at least at the senior 
end of schooling. In particular, the specific focus for the senior social studies curriculum for Year 1113 (ages 15-18) where students are can gain NCEA achievement credits if they take 'personal social action' has served to cement this focus further. Drawing on data collected as part of a Teaching and Learning Research Initiative project, Wood et al., (2017), showed that there has been a steady uptake of both senior social studies and the use of the social action standards, to the extent that by $2015,61 \%$ of New Zealand secondary schools were offering at least one Social Studies achievement standard. These data show that the integration of social action into the national assessment framework may have created a moment of possibility for a more 'active' approach to citizenship education in New Zealand than many earlier curriculum reforms. In many ways, this 2011 assessment policy shift which placed active citizenship participation (social action) into the suite of assessment credits available through NCEA - has driven greater participatory practice into social studies teaching and learning. While this was underpinned largely by neoliberal, $21^{\text {st }}$ century ideals for a certain type of active learner, the greater practice of social action has come about as a result of the possibility the 2007 curriculum offered.

However, while the growth and acceptance of social action in social studies has been steady, research shows that the types of social action students take still tends centre on personal and community-related actions. Wood et al. (2017) found that students' actions held more 'maximal' potential if they: (i) focused on personally and socially significant issues (these held greater meaning and authenticity for students); (ii) were underpinned by in-depth knowledge and critique of how and why the issues emerged (evidence-based and informed by a wide range of perspectives), and; (iii) developed an action strategy that matched the social issue and reached a range of interest groups, including those who held positions of power to inform change. The study also promisingly found that when students were well supported, undertaking social action was viewed by students (and their teachers) as highly valuable forms of citizenship learning about society, social issues, and skills for civic and community engagement (Wood et al., 2017).

\section{Seizing moments of possibility for citizenship education in the future}

This chapter contributes to wider debates about how citizenship curricula is positioned within an ensemble of competing political agendas, practitioner influences, and policy frameworks. Citizenship education in New Zealand has historically encountered several moments of possibility. The authors in this chapter have analysed five such moments which heralded either a growing or declining emphasis on the development of critical and active citizens. As Robertson and Dale (2015) remind us, such moments cannot be isolated and pinned down to one singular narrative or explanation - instead an ensemble of critical, cultural, political and economic factors shapes an event such as a curriculum development. The authors also remind us that at the moment of outcomes (Figure 1), it is important to not only take into account the unity of multiple determinations of such an outcome, but also the hierarchy of such contributing factors. The analysis of five such events in New Zealand citizenship 
education curriculum history points to a contested and erratic pattem - in which some held a greater and lesser potential for a critical citizenry to emerge.

The historical analysis places the current situation in New Zealand in a different position as regards citizenship education in both policy and practice from those settings in which the curriculum is tightly prescribed. In New Zealand, there is no specific citizenship education curriculum, although social studies takes responsibility for much of the content and related skills teaching. There are no mandated textbooks and the concepts are outlined in only the most general terms in the social studies achievement objectives and teacher support materials. Teachers have a high degree of autonomy in selecting both what and how they will teach. Yet, many New Zealand students appear to gain the appropriate knowledge, skills and dispositions that prepare them to be active and engaged citizens in their communities, their nation and on the global stage (Schulz, et al., 2010).

This high level of teacher autonomy offers a new moment of possibility. While the two particular themes identified in this chapter of social inquiry and social action build upon a legacy of these traditions in the New Zealand curriculum, and hold considerable opportunities for critical and active citizenship, the authors in prior work have all noted that social inquiry and social action and is less commonly 'political' or transformative in practice (Mutch et al., 2016; Wood \& Milligan, 2016; Wood et al., 2017). Nevertheless, at least since the 1970s, we have witnessed an expanding landscape of possibility, to the extent that there is now little that expressly precludes teachers from advancing a transformative approach to citizenship education through the social studies learning area. We believe that teachers have the capability to seize the possibility offered by the fertile ground of the accepted traditions of social inquiry and social action and drive a citizenship education for social transformation. What appears most needed, is not so much another iteration of the social studies curriculum - although a clearer explication of its citizenship intent is certainly warranted - but much stronger support for social studies teachers to take up its existing possibilities for critical and active citizenship. This chapter's historical and current analysis of citizenship education attests to the potential for transformative change through curriculum but also the potential for a minimal, contentheavy, and neoliberal approaches to learning citizenship in the absence of seizing the next moment of possibility.

\section{Cross references} TBC 


\section{References}

Abbiss, J. (1998). The "New Education Fellowship" in New Zealand. Its activity and influence in the 1930s and 1940s. New Zealand Journal of Educational Studies, 33(1).

Abbiss, J. (2011). Social sciences in the New Zealand Curriculum: Mixed messages. Curriculum Matters, 7(1), 118-137.

Alcorn, N. (1999). To the fullest extent of his powers. C.E. Beeby's life in education. Wellington: Victoria University Press.

Apple, M., Au, W., \& Gandin, L. A. (2009). Mapping critical education. In M. Apple, W. Au, \& L. A. Gandin (Eds.), The Routledge International Handbook of Critical Education (pp. 3-19). Hoboken: Routledge.

Archer, E., \& Openshaw, R. (1992). Citizenship and identity as 'official goals' in social studies. In R. Openshaw (Ed.), New Zealand Social Studies: Past, Present and Future (pp. 19-33). Palmerston North: Dunmore Press.

Bailey, C. (1997). A short survey of national education in New Zealand. Education 9, 2-11.

Bolstad, R. (2012). Participating and contributing? The role of school and community in supporting civic and citizenship education. Wellington, New Zealand: Ministry of Education.

Cornbleth, C. (1990). Curriculum in context. London: Falmer Press.

Dale, R. (13 November, 2017). The contradictions of education systems: Where are they now? Address to the School of Critical Studies in Education, The University of Auckland, New Zealand.

Dale, H. (2016). Te whanaketanga o te wahanga ako o te Tikanga a Iwi; Mai i te kore, ki wheiao, ki te ao marama; The development of the Tikanga a Iwi learning area: From nothingness, to halflight, to the full light of day. In M. Harcourt, A. Milligan, \& B. E. Wood (Eds.), Teaching social studies for critical, active citizenship in Aotearoa New Zealand (pp. 20-39). Wellington: NZCER.

Davies, I., Evans, M., \& Peterson, A. (2014). Civic activism, engagement and education: Issues and trends. Journal of Social Science Education, 13(4 Winter 2014), 1-10. doi:10.2390/jsse-v 13i4-1412

Department of Education. (1944). The post-primary school curriculum: Report of the Committee appointed by the Minister of Education in November, 1942 (The Thomas Report). Wellington: Government Printer.

Department of Education. (1961). Social studies in the primary school. Wellington: Government Printer.

Department of Education. (1977). Social studies syllabus guidelines: Forms 1-4. Wellington: Government Printer.

Gilbert, J. (2005). Catching the knowledge wave? The knowledge society and the future of education. Wellington: NZCER Press.

Keown, P. (1998). Values and social action: Doing the hard bits. In P. Benson \& R. Openshaw (Eds.), New horizons for New Zealand social studies (pp. 137-159). Palmerston North: ERDC Press.

Kliebard, H. (1986). The struggle for the American curriculum, 1893-1958. Boston: Routledge and Kegan Paul.

McLaren, I. (1980). Curriculum making in New Zealand 1877-1962. In D. Ramsay, (Ed.), Curriculum issues in New Zealand (pp. 13-31) Wellington, New Zealand: New Zealand Educational Institute.

McLaughlin, T. (1992). Citizenship, diversity and education: A philosophical perspective. Journal of Moral Education, 21(3), 235-250.

May, H. (2011). I am five and I go to school. Early years in schooling in New Zealand, 1900-2010. Dunedin, New Zealand: Otago University Press.

Ministry of Education. (1997). Social studies in the New Zealand curriculum. Wellington: Learning Media.

Ministry of Education. (2002). Curriculum stocktake report. Retrieved from Wellington: www.minedu.govt.nz

Ministry of Education. (2004). The New Zealand curriculum exemplars: Social studies. Wellington, NZ: Learning Media. 
Ministry of Education. (2007). The New Zealand curriculum. Wellington: Learning Media Ltd.

Ministry of Education. (2008a). Te marautanga o Aotearoa. Wellington, New Zealand: Learning Media.

Ministry of Education. (2008b). Building conceptual understandings in the social sciences: Approaches to social inquiry. Wellington, NZ: Learning Media.

Ministry of Education. (2008c). Building conceptual understandings in the social sciences: Belonging and participating in society. Wellington, NZ: Learning Media.

Ministry of Education. (2009). Building conceptual understandings in the social sciences: Being part of global communities. Wellington, NZ: Learning Media.

Ministry of Education. (2011). The New Zealand curriculum update: the future focus principle. Issue 15. Retrieved from: http://nzcurriculum.tki.org.nz/Curriculum-resources/NZC-Updates

Ministry of Education. (2012). Building conceptual understandings in the social sciences: Taking part in economic communities. Wellington, NZ: Learning Media.

Mutch, C. (2004). Curriculum construction as a social field: Mapping the process of the development of the New Zealand social studies curriculum. Curriculum Perspectives 24(3) 22-33.

Mutch, C. (2008). 'Creative and innovative citizenry:' Exploring the past, present and future of citizenship education in New Zealand. In D. Grossman, W. On Lee, \& K. Kennedy (Eds.), Citizenship education in Asia and the Pacific (pp. 197-203). Hong Kong/Dortrecht, The Netherlands: Comparative Education Research Centre/Springer.

Mutch, C. (2010). Embedding education for citizenship into pedagogical practices: The case of New Zealand. In K. Kennedy, W.O. Lee, \& D. Grossman, (Eds.), Pedagogy for citizenship in the Asia-Pacific (pp. 291-313). Hong Kong/Dortrecht, The Netherlands: Comparative Education Research Centre/Springer.

Mutch, C., Hunter, P., Milligan, A., Openshaw, R., \& Siteine, A. (2008). Understanding the social sciences as a learning area: A position paper. Wellington Retrieved from http://nzcurriculum.tki.org.nz/Media/Files/UV-files/Understanding-the-social-sciences-as-alearning-area-A-position-paper-February-2008.

Mutch, C., Perreau, M., Houliston, B., \& Tatebe, J. (2016). Teaching social studies for social justice: Social action is more than 'doing stuff'. In M. Harcourt, A. Milligan, \& B. E. Wood (Eds.), Teaching social studies for critical, active citizenship in Aotearoa New Zealand (pp. 82-101). Wellington: NZCER.

Nelson, J., \& Kerr, D. (2006). Active citizenship in INCA countries: Definitions, policies, practices, and outcomes. London: NFER/QCA Retrieved from http://www.inca.org.uk/pdf/Active_Citizenship_Report.pdf.

OECD. (1996). The knowledge-based economy. Retrieved from Paris:

OECD. (2005). The definition and selection of key competencies: Executive summary. Paris: OECD Retrieved from http://www.pisa.oecd.org/dataoecd/47/61/35070367.pdf.

Openshaw, R. (2000). Culture wars in the Antipodes: The social studies curriculum controversy in New Zealand. Theory and Research in Social Education, 28(1), 65-84. doi.org/10.1080/00933104.2000.10505897

Perreau, M. \& Kingsbury, L. (2017). The Anzac Iliad: Early New Zealand School Journals and the development of the citizen-child in the new dominion. Citizenship, Social and Economics Education 16(3), 157-173.

Robertson, S. L., \& Dale, R. (2015). Towards a 'critical cultural political economy' account of the globalising of education. Globalisation, Societies and Education, 13(1), 149-170. doi:10.1080/14767724.2014.967502

Ross, A. (2008). Organizing a curriculum for active citizenship education. In J. Arthur, I. Davies, \& C. Hahn (Eds.), The Sage handbook of education for citizenship and democracy (pp. 492505). London: Sage.

Schulz, W., Ainley, J., Fraillon, J., Kerr, D., \& Losito, B. (2010). ICCS 2009 International Report: Civic knowledge, attitudes, and engagement among lower-secondary students in 38 countries. Retrieved from Amsterdam: 
http://www.iea.nl/fileadmin/user_upload/Publications/Electronic_versions/ICCS_2009_Intem ational_Report.pdf

Shuker, R. (1992). The one best system: A revisionist history of state schooling in New Zealand. Palmerston North, New Zealand: Dunmore Press.

Simon, J. (1994). Historical perspectives on education in New Zealand. In E. Coxon, K. Jenkins, J. Marshall, \& L. Massey (Eds.), The politics of teaching and learning in Aotearoa New Zealand. Palmerston North: Dunmore Press.

Tallon, R., \& Milligan, A. (2018). The changing field of development and global education resource provision in New Zealand. International Journal of Development Education and Global Learning, 10(1), 59-71

Taylor, R. (2008). Teachers' conflicting responses to change: An evaluation of the implementation of senior social studies for the NCEA 2002-2006. (EdD Doctor of Education thesis), Massey University, Palmerston North.

Wood, B. E., \& Milligan, A. (2016). Citizenship education in New Zealand: Policy and practice. Policy Quarterly, 12(3), 65-73. Retrieved from http://igps.victoria.ac.nz/publications/files/156006894e5.pdf

Wood, B. E., \& Sheehan, M. (2012). Dislodging knowledge? The New Zealand Curriculum in the 21 st century. Pacific-Asian Education, 24(1), 17-30.

Wood, B. E., Taylor, R., \& Atkins, R. (2013). Fostering active citizenship in social studies: Teachers' perceptions and practices of social action. New Zealand Journal of Educational Studies, 48(2), 84-98.

Wood, B. E., Taylor, R., Atkins, R., \& Johnston, M. (2017). Creating active citizens? Interpreting, implementing and assessing 'personal social action' in NCEA social studies: Final Report. Retrieved from Wellington:

http://www.tlri.org.nz/sites/default/files/projects/TLRI\%20Summary_Wood\%28v2\%29.pdf 